\title{
Pogranicze jako kategoria politologiczna
}

Lech Rubisz ${ }^{1}$

Link do artykułu:

http://pogranicze.uni.opole.p1/biblioteka/docs/nr1/rubisz_nr1.pdf

Standard cytowania (APA):

Rubisz, L. (2013). Pogranicze jako kategoria politologiczna. Pogranicze. Polish Borderlands Studies, $n r$ 1, s. 76-77.

Przyimek ,jako", który posłużył do zdefiniowania tytułowego problemu, okazuje się często wykorzystywaną przez politologów a dla teorii polityki pomocną częścią mowy (zob. Metafory polityki, Kaczmarek 2001; 2003; 2005). Pozwala on bowiem na budowanie takich konstrukcji gramatycznych, które otwierają możliwości metaforycznych wyjaśnień polityki, poszukiwania tego co polityczne w różnych obszarach rzeczywistości społecznej. Formuła „pogranicze jako kategoria politologiczna”, jak w wielu innych przypadkach, trafnie ilustruje refleksyjną, ktoś mógłby powiedzieć niepewną, naukowość politologii. Wprost nie jest ani twierdzeniem, ani nie jest pytaniem, ale nietrudno w niej dostrzec uprawdopodobnione przekonanie o polityczności pogranicza i zarazem niewiadomą, na czym owa polityczność polega. Tak więc tytułowy problem sprowadza się w rezultacie tylko do oznaczenia zakresu i stopnia polityczności zjawiska pogranicza, określenia - co narzuca forma przyimkowa jakie są jego polityczne cechy i polityczne funkcje. W tym sensie jak sądzę - można mówić raczej o politologiczności kategorii pogranicze, albo - o pograniczu jako przedmiocie badań politologicznych. Brzmi to bardziej miękko (realistycznie) niż „pogranicze jako kategoria politologiczna".

Pogranicze pod względem strukturalnym, to zjawisko społeczne nierozłącznie powiązane $\mathrm{z}$ obszarem. I najczęściej w takim znaczeniu rozumie się je jako kategorię samoistną, przynależną przede wszystkim do socjologii i antropologii kulturowej. Takie dyscypliny, jak choćby politologia, historia czy psychologia społeczna czynią z pogranicza przedmiot swoich badań tylko w takim zakresie, jaki wyznacza im ich przedmiotowy charakter i epistemologiczne właściwości. Możemy mówić oczywiście o pograniczu jako pojęciu politologicznym, ale wówczas mielibyśmy na myśli jedynie obszar, pas przyległy do granic oddzielających dwa państwa, albo na przykład jakąś strefę wielości i nieokreśloności między ideologiami, programami czy partiami politycznymi. To byłoby jednak tylko użyteczne pojęcie, a nie kategoria, a o nią w tym przypadku przecież chodzi.

Gdzie zatem szukać politologiczności kategorii pogranicze, a tym samym polityczności zarówno w zjawisku, jak i w obszarze. Sądzę, że nasycenie politycznością występuje tu głównie na dwóch poziomach - poziomie genezy i poziomie skutków, w tym sensie więc na jego obrzeżach. Geneza kształtowania się, czy samego trwania pogranicza (nasycania treścią tej kategorii) tkwi często w faktach, zjawiskach czy procesach stricte politycznych. Można wymienić takie przypadki, jak: wyznaczanie granic między państwami według kryteriów politycznych, wojny, międzygrupowa rywalizacja o dostęp do władzy, polityczna dominacja większości nad mniejszością, dążenie mniejszości do

1 Dr Lech Rubisz: dyrektor Instytutu Politologii Uniwersytetu Opolskiego. 
politycznej autonomizacji, przemieszczanie ludności w wyniku decyzji państwowych itp. Polityczność pogranicza odnajdujemy także na poziomie jego skutków. Tu wystarczy odwołać się do dwóch spośród wielu przykładów: tworzenia oraz działalności partii i innych organizacji artykulacji interesów narodowościowych lub etnicznych czy polityzację problemów pogranicza przez partie państw sąsiadujących i nie tylko takich (zob. kwestia praw człowieka). W sposób oczywisty poziom politycznych skutków może wtórnie wzmacniać poziom politycznej genezy. Te i inne przykłady polityczności pogranicza nie muszą determinować któregoś $\mathrm{z}$ dwóch jego biegunowych wyobrażeń - konsensualnego lub konfliktowego. Chociaż intuicja, a może bardziej stereotyp podpowiada, że upolitycznianie zjawiska pogranicza sprzyja konfliktowi - im więcej polityki w $\mathrm{z}$ natury społecznym zjawisku, tym konflikt bardziej przesądzony. Wcale tak nie musi być. Polityczność bowiem, $i$ to we wszystkich wymienionych przykładach, zwłaszcza gdy idzie pod rękę z demokracją, może na pograniczu sprzyjać również tolerancji, pokojowemu współżyciu, twórczej różnorodności, budowaniu kapitału społecznego, zbliżeniu państw, narodów czy kultur.

Przyjmując, że tytułowy problem kończy się domyślnym znakiem zapytania, to właśnie w tym, co powyżej zostało jedynie zasygnalizowane, widziałbym politologiczny aspekt(ty) kategorii pogranicza.

\section{Literatura:}

Kaczmarek, B. (red.). (2001). Metafory polityki. Warszawa: Dom Wydawniczy Elipsa.

Kaczmarek, B. (red.). (2003). Metafory polityki, tom 2. Warszawa: Dom Wydawniczy Elipsa.

Kaczmarek, B. (red.). (2005). Metafory polityki, tom 3. Warszawa: Dom Wydawniczy Elipsa. 